\title{
Comparison of Brown Midrib Sorghum-Sudangrass with Corn Silage on Lactational Performance and Nutrient Digestibility in Holstein Dairy Cows
}

\author{
H. M. Dann, ${ }^{*}$ R. J. Grant, ${ }^{* 1}$ K. W. Cotanch, ${ }^{*}$ E. D. Thomas, ${ }^{\star}$ C. S. Ballard, ${ }^{\star}$ and R. Rice \\ *W. H. Miner Agricultural Research Institute, Chazy, NY 12921 \\ †Garrison \& Townsend Inc., Hereford, TX 79045
}

\begin{abstract}
Total mixed rations containing brown midrib sorghum-sudangrass silage (bmrSS) or corn silage (CS) at either 35 or $45 \%$ of dietary dry matter were fed to Holstein dairy cows to determine the effect on lactational performance and nutrient digestibility. Twelve cows were assigned to 1 of 4 diets in replicated $4 \times 4$ Latin squares with 21 -d periods. In vitro 30 -h neutral detergent fiber digestion, measured before the start of the trial, was $46.0 \%$ for CS and $58.3 \%$ for bmrSS. Dry matter intake was greatest when cows were fed the $35 \%$ CS $(23.4 \mathrm{~kg} / \mathrm{d})$ and $45 \% \mathrm{CS}(23.2 \mathrm{~kg} / \mathrm{d})$ diets, was least when cows were fed the $45 \% \mathrm{bmrSS}$ diet $(17.6 \mathrm{~kg} / \mathrm{d})$, and was intermediate when cows were fed the $35 \%$ bmrSS diet $(20.1 \mathrm{~kg} / \mathrm{d})$. The bmrSS diets resulted in greater body weight gain per 21-d period but similar body condition scores compared with the CS diets. Yield of solids-corrected milk (SCM) was similar among the diets. Efficiency (SCM:dry matter intake) was $28 \%$ greater for cows fed the bmrSS than those fed the CS diets. In vivo digestibilities of organic matter and crude protein were greater for the CS diets than the bmrSS diets, but total tract digestibilities of neutral detergent fiber and starch were similar among diets. Ruminal $\mathrm{pH}$ was greater when cows were fed the $45 \%$ bmrSS diet (6.58), was least when cows were fed the $35 \%$ CS (6.10) and $45 \%$ CS diets (6.13), and was intermediate when cows were fed the $35 \%$ bmrSS diet (6.42). The ratio of acetate to propionate was greater for the bmrSS diets (2.77) than for the CS diets (2.41), with no difference among diets in total volatile fatty acid concentrations $(122 \mathrm{mM})$. In conclusion, cows fed bmrSS had greater efficiency of SCM production, higher ruminal $\mathrm{pH}$, and greater acetate to propionate ratios than cows fed CS. With these diets fed in a short-term study, bmrSS ap-
\end{abstract}

Received August 16, 2007.

Accepted October 4, 2007.

${ }^{1}$ Corresponding author: grant@whminer.com peared to be an effective alternative to the CS hybrid when fed at either 35 or $45 \%$ of dietary dry matter.

Key words: brown midrib, sorghum-sudangrass, corn silage, lactation

\section{INTRODUCTION}

Climatic conditions such as drought, delayed planting because of wet soil conditions, and high summer temperatures introduce considerable risk into corn production for silage. Silage-type sorghums have been investigated as a viable alternative crop because they can be planted later than corn, use water more efficiently, have high biomass yields, increase soil cover, reduce soil erosion, and have a low requirement for pesticides (Sanderson et al., 1992). Sorghum-sudangrass hybrids have a 2- to 3-cut harvest schedule that is compatible with many forage programs and that allows manure application during summer. They provide opportunities for double cropping and are compatible with grazing (Kilcer et al., 2001). However, the nutrient digestibility of many corn hybrids is greater than that for conventional forage sorghum or sorghum-sudangrass hybrids.

Brown midrib (bmr) forage genotypes typically contain less lignin and may have altered lignin composition and cross-linking with cell wall carbohydrates, resulting in improved NDF digestibility (Vogel and Jung, 2001). Although $3 \mathrm{bmr}$ loci have been identified in sorghum (bmr-6, bmr-12, and bmr-18; Porter et al., 1978), most research has focused on bmr-6 sorghum. In vitro and in situ digestion studies have shown that bmr forage sorghum and bmr sorghum-sudangrass hybrids have a greater extent of NDF digestion than their conventional counterparts (Fritz et al., 1990; Grant et al., 1995).

Previous research (Aydin et al., 1999; Oliver et al., 2004) showed that bmr-6 forage sorghum resulted in greater cell wall digestibility and lactational performance when fed to dairy cows compared with a non$\mathrm{bmr}$ forage sorghum. These same studies found that lactational performance was similar for cows fed the bmr-6 forage sorghum or a dual-purpose corn hybrid 
commonly grown in the Midwestern United States. However, research is needed to compare bmr sorghumsudangrass hybrids with other common forages and to develop alternatives to corn silage $(\mathbf{C S})$ in regions or situations where corn is less agronomically suitable. To date, there have been no studies designed to evaluate the effect of incorporating bmr-6 sorghum-sudangrass hybrids into lactation diets in place of dual-purpose CS on nutrient digestibility, DMI, and milk production. Diets formulated by substituting bmr sorghum-sudangrass for CS at different dietary forage percentages would differ markedly in their content of NDF, digestible NDF from forage, and NFC, which could potentially have a large impact on the cow response.

Therefore, the objective of this study was to determine the effect of substituting a bmr-6 sorghum-sudangrass hybrid for a dual-purpose corn hybrid, at 2 concentrations of dietary forage, on short-term lactational performance and nutrient digestibility when fed to lactating Holstein dairy cows.

\section{MATERIALS AND METHODS}

\section{Sorghum-Sudangrass and Corn Cultivation, Harvest, and Chemical Composition}

All forages used in this experiment were harvested in 2003 at the William H. Miner Agricultural Research Institute in Chazy, New York. Brown midrib-6 sorghum-sudangrass (bmr 201, Garrison \& Townsend Inc., Hereford, TX) was planted June 23, 2003, and harvested August 18 and 19, 2003, at the early-heading stage of maturity. The DM yield was $4,930 \mathrm{~kg} / \mathrm{ha}$. Corn (Syngenta N3030, Syngenta Seeds Inc., Golden Valley, MN) was planted May 18, 2003, and harvested September 26, 2003, at the two-thirds milk-line stage of maturity. The DM yield was $14,117 \mathrm{~kg} / \mathrm{ha}$. The forages were harvested by using a Gehl 1265 field chopper (Gehl Company, West Bend, WI) with knives adjusted to a 19-mm theoretical length of cut and processed with a 3 -mm roller clearance. The forages were ensiled without the use of inoculants in separate plastic silage bags (Ag-International Ltd., Warrenton, OR). The lactation experiment began in June 2004. The chemical composition of the experimental CS and bmr sorghum-sudangrass silage (bmrSS), an alfalfa-grass silage used in all diets, and the concentrate mix for experimental diets is summarized in Table 1.

\section{Cows and Dietary Treatments}

Twelve Holstein dairy cows (4 primiparous and 8 multiparous with 4 ruminally fistulated) were assigned randomly within parity and fistulation status to 1 of 4 diets in a replicated $4 \times 4$ Latin square (squares were conducted concurrently) with 21-d periods; the first 14 $\mathrm{d}$ served as an adaptation period and the last $7 \mathrm{~d}$ served as the collection period. Cows averaged $81 \pm 31 \mathrm{DIM}$ at the beginning of the experiment. Diets contained either bmrSS or CS at 2 inclusion levels: 35 or $45 \%$ of dietary DM (Table 2). The control diet was formulated for a cow at 120 DIM with a BCS of 3.00 , a BW of $635 \mathrm{~kg}$, a DMI of $24 \mathrm{~kg} / \mathrm{d}$, and a milk yield of $37 \mathrm{~kg} / \mathrm{d}$ containing $3.7 \%$ fat and 3.0\% true protein (CPM-Dairy nutrition model, version 3.0, University of Pennsylvania, New Bolton Center, PA). Diets were fed as TMR (Calan Data Ranger, American Calan Inc., Northwood, $\mathrm{NH})$. Cows were housed in a tie-stall barn equipped with individual feed boxes. Cows were fed individually for ad libitum intake (approximately 105\% of expected intake) once daily $(0900 \mathrm{~h})$. Cows were removed from the barn twice daily (0600 and $1800 \mathrm{~h}$ ) for milking in a double-12 parallel milking parlor (Xpressway Parallel Stall System, Bou-Matic, Madison, WI).

\section{Sample Collection and Analysis}

Milk yields were recorded electronically (ProVantage Information Management System, Bou-Matic) on d 15 to 21 of each period. Milk samples were collected during the a.m. and p.m. milkings on d 18 and 19 of each period. The milk samples were analyzed at a commercial laboratory (Dairy One, Ithaca, NY) for fat, true protein, lactose, urea nitrogen, and SCC by mid-infrared procedures (Foss 4000, Foss Technology, Eden Prairie, MN; AOAC, 2000). Calculation of milk composition was weighted according to a.m. and p.m. milk yields. The FCM and ECM yields were calculated according to Tyrrell and Reid (1965).

Body weight and BCS (Wildman et al., 1982) were determined for each cow at the beginning of the experiment and at the end of each period immediately after the a.m. milking. Feed intake was determined by recording feed offered daily (d 17 to 20 ) and collecting orts daily (d 18 to 21) for each cow during the last week of each period. Samples of diets (d 17 to 20), orts (d 18 to 21), and individual feed ingredients (d 17 to 20) were collected and a portion of each sample was dried in a forced-air oven at $60^{\circ} \mathrm{C}$ for $24 \mathrm{~h}$ for DM determination. Diets were adjusted weekly for changes in the DM content of the ensiled forages. The remaining portion of each sample was composited by period. A portion of the composited samples was submitted to a commercial laboratory for wet chemistry analysis (Dairy One). Diet and individual feed ingredient samples were submitted on an as-fed basis; ort samples were dried $\left(60^{\circ} \mathrm{C}\right.$ for 18 to $24 \mathrm{~h}$ ) and ground to pass through a 1-mm screen (Wiley mill, Arthur H. Thomas, Philadelphia, PA) and then submitted. Dry matter (method 930.15), CP 
Table 1. Chemical composition, fermentation analysis, and in vitro digestibility (\% of DM) of ingredients used in the brown midrib sorghumsudangrass-based and corn silage-based diets

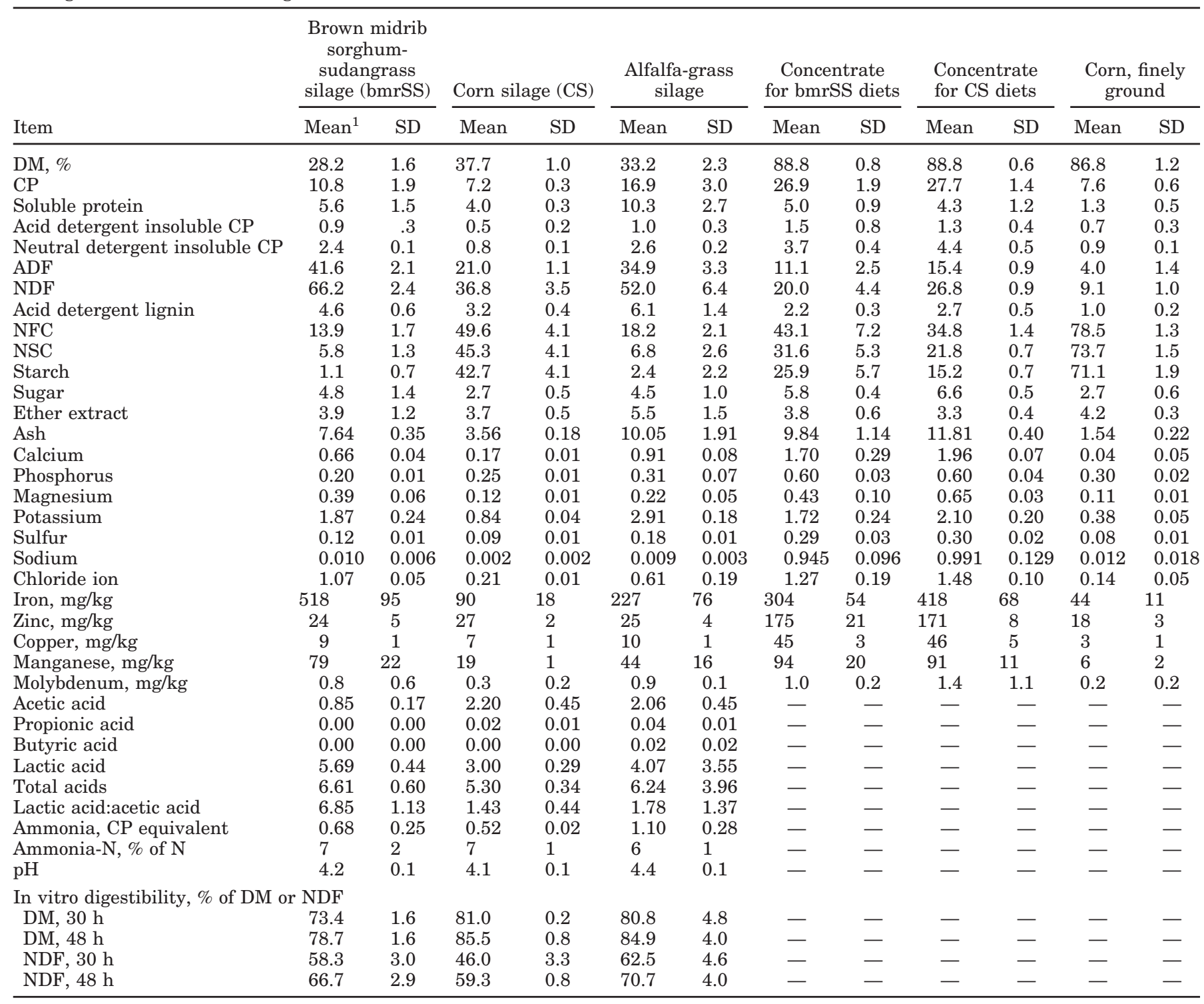

${ }^{1}$ Mean of 4 composite samples (one per period).

(method 990.03), and ash (method 942.05) were determined according to AOAC (2000) methods. Soluble protein was determined with a sodium borate, sodium phosphate buffer procedure (Roe and Sniffen, 1990). Nonstructural carbohydrates and sugars were determined by the procedures of Hall et al. (1999) and Smith (1969), where ferricyanide was used to detect reducing sugars. Starch was determined with a YSI 2700 Select biochemistry analyzer (application note 319, YSI Incorporated, Yellow Springs, OH). Acid detergent fiber with residual ash, amylase-modified NDF (aNDF) with residual ash (using $\alpha$-amylase and sodium sulfite), and acid detergent lignin were determined by using the An- kom A200 filter bag technique (Ankom Technology Corp., Fairport, NY; Van Soest et al., 1991). Neutral detergent insoluble $\mathrm{CP}$ and acid detergent insoluble $\mathrm{CP}$ were determined by analyzing $\mathrm{aNDF}$ and $\mathrm{ADF}$ residues for Kjeldahl nitrogen (Licitra et al., 1996). Ether extract was measured by using the automated Tecator Soxtec System HT6 (application note AN 301, Foss North America, Eden Prairie, MN). Calcium, phosphorus, magnesium, potassium, sodium, iron, zinc, copper, manganese, and molybdenum were measured by using a Thermo Jarrell Ash Iris Advantage inductively coupled plasma radial spectrometer (model ICAP 61, Thermo Jarrell Ash, Ithaca, NY; Sirois et al., 1994). 
Table 2. Ingredient composition of diets (\% of DM) containing brown midrib sorghum-sudangrass silage (bmrSS) or corn silage (CS) at 35 or $45 \%$ of dietary DM

\begin{tabular}{|c|c|c|c|c|}
\hline \multirow[b]{2}{*}{ Item } & \multicolumn{4}{|c|}{ Diet } \\
\hline & $\begin{array}{c}35 \% \\
\text { bmrSS }\end{array}$ & $\begin{array}{c}45 \% \\
\text { bmrSS }\end{array}$ & $\begin{array}{l}35 \% \\
\mathrm{CS}\end{array}$ & $\begin{array}{c}45 \% \\
\mathrm{CS}\end{array}$ \\
\hline bmrSS & 34.63 & 43.99 & - & - \\
\hline CS & - & - & 35.32 & 44.87 \\
\hline Alfalfa-grass silage & 9.36 & 9.36 & 9.55 & 9.55 \\
\hline Corn, finely ground & 28.54 & 19.18 & 17.44 & 7.89 \\
\hline Soybean meal, $48 \% \mathrm{CP}$ & 9.33 & 9.33 & 9.73 & 9.73 \\
\hline Canola meal & 6.53 & 6.53 & 6.68 & 6.68 \\
\hline Corn germ meal & 4.67 & 4.67 & 4.78 & 4.78 \\
\hline Soybean hulls & - & - & 7.68 & 7.6 \\
\hline EnerGII $^{1}$ & 1.89 & 1.89 & 1.93 & 1.9 \\
\hline AminoPlus $^{2}$ & 2.19 & 2.19 & 3.18 & 3.1 \\
\hline Alimet $^{3}$ & 0.03 & 0.03 & 0.03 & 0. \\
\hline Urea & 0.19 & 0.19 & 0.19 & 0.19 \\
\hline Sodium bicarbonate & 0.65 & 0.65 & 0.66 & 0.66 \\
\hline Potassium bicarbonate & 0.42 & 0.42 & 0.78 & 0.78 \\
\hline Calcium carbonate & 0.84 & 0.84 & 1.18 & 1.18 \\
\hline Sodium chloride & 0.52 & 0.52 & 0.52 & 0.52 \\
\hline Magnesium oxide & 0.13 & 0.13 & 0.28 & 0.2 \\
\hline Vitamin E supplement ${ }^{4}$ & 0.01 & 0.01 & 0.01 & 0.0 \\
\hline Selenium supplement ${ }^{5}$ & 0.03 & 0.03 & 0.03 & 0.0 \\
\hline Trace mineral mix $1^{6}$ & 0.02 & 0.02 & 0.02 & 0.0 \\
\hline Trace mineral mix $2^{7}$ & 0.02 & 0.02 & 0.02 & 0.02 \\
\hline Vitamin premix ${ }^{8}$ & 0.01 & 0.01 & 0.01 & 0.01 \\
\hline
\end{tabular}

\footnotetext{
${ }^{1}$ Bioproducts Inc., Fairlawn, OH.

${ }^{2} \mathrm{Ag}$ Processing Inc., Omaha, NE.

${ }^{3}$ Novus International Inc., St. Louis, MO.

${ }^{4}$ Contained 44,100 kIU/kg.

${ }^{5}$ Contained $606 \mathrm{mg} / \mathrm{kg}$.

${ }^{6}$ Contained $1.0 \% \mathrm{Ca}, 8.8 \% \mathrm{~S}, 4,102 \mathrm{mg}$ of Fe/kg, 102,044 mg of Zn/kg, 20,425 mg of Cu/kg, 81,681 mg of $\mathrm{Mn} / \mathrm{kg}, 775 \mathrm{mg}$ of $\mathrm{Co} / \mathrm{kg}$, and $1,419 \mathrm{mg}$ of $\mathrm{I} / \mathrm{kg}$.

${ }^{7}$ Contained $7.1 \% \mathrm{Ca}, 0.19 \% \mathrm{Mg}, 7.9 \% \mathrm{~S}, 10,714 \mathrm{mg}$ of $\mathrm{Fe} / \mathrm{kg}, 214,285 \mathrm{mg}$ of $\mathrm{Zn} / \mathrm{kg}, 41,326 \mathrm{mg}$ of Cu$/ \mathrm{kg}$, $107,142 \mathrm{mg}$ of $\mathrm{Mn} / \mathrm{kg}, 841 \mathrm{mg}$ of Se/kg, 2,448 mg of Co/kg, and 2,040 mg of I/kg.

${ }^{8}$ Contained $9.86 \% \mathrm{Ca}, 0.06 \% \mathrm{P}, 1.05 \% \mathrm{Mg}, 1.33 \% \mathrm{~K}, 0.04 \% \mathrm{~S}, 0.53 \% \mathrm{Na}, 0.08 \% \mathrm{Cl}, 35,946 \mathrm{kIU}$ of vitamin $\mathrm{A} / \mathrm{kg}, 12,247 \mathrm{kIU}$ of vitamin $\mathrm{D} / \mathrm{kg}$, and $44,535 \mathrm{IU}$ of vitamin $\mathrm{E} / \mathrm{kg}$.
}

Sulfur was measured by using an elemental analyzer (application note 203-601-229, 08/92, model SC-432, Leco Corporation, St. Joseph, MI; Sirois et al., 1994). The chloride ion was measured by using a potentiometric titrator (application bulletin 130, Brinkmann Metrohm 716 Titrino titration unit with silver electrode, Brinkmann Instruments Inc., Westbury, NY). Nonfiber carbohydrate was calculated as $100-[\mathrm{CP}+($ aNDF neutral detergent insoluble $\mathrm{CP}$ ) + ether extract $+\mathrm{ash}]$. Analysis of VFA was performed with a gas chromatographic separation procedure (Supelco Bulletin 749E, Supelco Inc., Bellefonte, PA).

Another portion of the composite sample of each diet was used to determine particle size distribution (Table 4) on an as-fed basis with a Penn State Particle Separator (Lammers et al., 1996; Kononoff et al., 2003) and on a DM basis with a Ro-Tap testing sieve shaker (model B, W. S. Tyler Combustion Engineering Inc., Mentor, OH).

Fecal grab samples were collected on d 18 to 21 of each period so that every $3 \mathrm{~h}$ in a 24 -h period was represented (8 samples total). Fecal samples from each cow were composited by combining approximately 100 $\mathrm{g}$ of feces from each time point. Samples were frozen at $-20^{\circ} \mathrm{C}$, dried in a forced-air oven at $60^{\circ} \mathrm{C}$ for $48 \mathrm{~h}$, ground to pass through a 1-mm screen (Wiley mill, Arthur H. Thomas), and submitted for wet chemistry analysis (Dairy One).

Total tract digestibilities of DM, OM, CP, ADF, NDF, starch, NFC, and phosphorus were determined on d 17 to 21 of each period. Indigestible NDF was used as an internal marker. Indigestible NDF residue in diets, orts, and feces was quantified as the NDF content of samples following an in vitro fermentation (Ankom Technology Corp.) in buffered rumen media (Goering and Van Soest, 1970) for $120 \mathrm{~h}$. Total tract digestibility was calculated by the ratio technique using the concentration of the nutrients and indigestible NDF in the diet and feces (Maynard et al., 1979). The nutrient content of the diet used in the digestibility calculation was adjusted for each cow based on the nutrient composition 
Table 3. Chemical composition (\% of DM) of diets containing brown midrib sorghum-sudangrass silage (bmrSS) or corn silage (CS) at 35 or $45 \%$ of dietary DM

\begin{tabular}{|c|c|c|c|c|c|c|c|c|}
\hline \multirow[b]{3}{*}{ Item } & \multicolumn{8}{|c|}{ Diet } \\
\hline & \multicolumn{2}{|c|}{$35 \%$ bmrSS } & \multicolumn{2}{|c|}{$45 \% \mathrm{bmrSS}$} & \multicolumn{2}{|c|}{$35 \% \mathrm{CS}$} & \multicolumn{2}{|c|}{$45 \% \mathrm{CS}$} \\
\hline & Mean $^{1}$ & SD & Mean & SD & Mean & SD & Mean & SD \\
\hline $\mathrm{DM}, \%$ & 45.1 & 1.7 & 39.8 & 1.5 & 52.9 & 1.1 & 49.1 & 1.2 \\
\hline $\mathrm{CP}$ & 18.0 & 1.2 & 17.0 & 2.3 & 17.3 & 0.7 & 17.4 & 1.4 \\
\hline Soluble protein & 6.0 & 0.6 & 6.1 & 0.7 & 4.8 & 0.7 & 5.1 & 0.6 \\
\hline Acid detergent insoluble $\mathrm{CP}$ & 0.9 & 0.4 & 0.8 & 0.3 & 1.0 & 0.5 & 0.9 & 0.5 \\
\hline Neutral detergent insoluble CP & 2.9 & 0.3 & 2.9 & 0.1 & 2.5 & 0.2 & 2.5 & 0.2 \\
\hline $\mathrm{ADF}$ & 24.4 & 2.7 & 29.9 & 3.2 & 18.9 & 1.8 & 20.9 & 1.9 \\
\hline $\mathrm{NDF}$ & 40.3 & 3.2 & 48.2 & 5.8 & 31.1 & 2.6 & 34.2 & 2.3 \\
\hline Acid detergent lignin & 4.2 & 0.8 & 5.0 & 1.1 & 3.3 & 0.6 & 3.5 & 0.7 \\
\hline NFC & 31.7 & 3.4 & 24.6 & 3.6 & 43.4 & 2.8 & 39.8 & 2.0 \\
\hline NSC & 22.5 & 2.7 & 15.3 & 3.2 & 34.8 & 4.0 & 32.3 & 1.5 \\
\hline Starch & 16.9 & 2.5 & 9.5 & 3.9 & 30.4 & 3.8 & 27.8 & 1.4 \\
\hline Sugar & 5.6 & 1.7 & 5.9 & 1.3 & 4.5 & 0.3 & 4.5 & 0.4 \\
\hline Ether extract & 4.7 & 0.3 & 4.4 & 0.4 & 4.6 & 0.4 & 4.5 & 0.5 \\
\hline Ash & 8.33 & 0.41 & 8.72 & 0.42 & 7.10 & 0.40 & 7.59 & 0.51 \\
\hline Calcium & 1.05 & 0.19 & 1.00 & 0.10 & 0.89 & 0.07 & 0.93 & 0.08 \\
\hline Phosphorus & 0.35 & 0.01 & 0.32 & 0.04 & 0.36 & 0.02 & 0.36 & 0.02 \\
\hline Magnesium & 0.33 & 0.02 & 0.35 & 0.02 & 0.32 & 0.02 & 0.32 & 0.02 \\
\hline Potassium & 1.71 & 0.20 & 1.91 & 0.31 & 1.51 & 0.14 & 1.58 & 0.09 \\
\hline Sulfur & 0.20 & 0.01 & 0.19 & 0.04 & 0.18 & 0.01 & 0.18 & 0.01 \\
\hline Sodium & 0.38 & 0.03 & 0.38 & 0.03 & 0.41 & 0.03 & 0.41 & 0.02 \\
\hline Chloride ion & 0.98 & 0.14 & 0.10 & 0.08 & 0.81 & 0.11 & 0.78 & 0.11 \\
\hline Iron, $\mathrm{mg} / \mathrm{kg}$ & 365 & 54 & 413 & 55 & 227 & 41 & 225 & 20 \\
\hline Zinc, $\mathrm{mg} / \mathrm{kg}$ & 88 & 7 & 80 & 27 & 93 & 7 & 92 & 10 \\
\hline Copper, mg/kg & 21 & 2 & 19 & 3 & 19 & 1 & 19 & 1 \\
\hline Manganese, $\mathrm{mg} / \mathrm{kg}$ & 76 & 9 & 82 & 9 & 53 & 3 & 57 & 6 \\
\hline Molybdenum, mg/kg & 0.9 & 0.3 & 0.9 & 0.3 & 0.6 & 0.2 & 0.6 & 0.2 \\
\hline
\end{tabular}

${ }^{1}$ Mean of 4 composite samples (one per period).

of the diet offered and refused. Diets and fecal samples were analyzed for DM, ash, CP, NFC, starch, ADF, aNDF, and acid detergent lignin at a commercial laboratory (Dairy One) as described previously.

Samples of ruminal fluid $(\sim 250 \mathrm{~mL})$ were collected from beneath the ruminal digesta mat at 4 -h intervals for $24 \mathrm{~h}$ on $\mathrm{d} 20(0800,1200,1600$, and $2000 \mathrm{~h})$ and 21 (0000 and $0400 \mathrm{~h}$ ) of each period. Samples were strained through 4 layers of cheesecloth. The $\mathrm{pH}$ of ruminal fluid was determined immediately following collection. Ruminal fluid (approximately $40 \mathrm{~mL}$ ) was then frozen and stored at $-20^{\circ} \mathrm{C}$ until VFA determination (Bulletin 856B, Supelco Inc.). Volatile fatty acids were extracted from ruminal samples by soaking samples in Milli-Qgrade water (Millipore Corporation, Bedford, MA) at a $1 \mathrm{~g}: 2 \mathrm{~mL}$ ratio overnight at $4^{\circ} \mathrm{C}$. After an initial cheesecloth filtration, the extracts were centrifuged at $200 \times$ $g$ for $10 \mathrm{~min}$ and then filtered through a disposable syringe filter. Final extracts were mixed with equal parts of an internal standard $(50 \mu \mathrm{mol} / \mathrm{mL}$ of trimethylacetic acid in $0.06 \mu \mathrm{mol}$ of oxalic acid) prior to a 1$\mu \mathrm{L}$ flash on-column injection. The VFA concentrations were determined by gas chromatography with a Varian CP-3800 gas chromatograph (Varian Inc., Palo Alto,
CA) containing an 80/120 Carbopack B-DA/4\% Carbowax 20M column (Supelco Inc.).

Phosphorus balance was determined on $\mathrm{d} 17$ to 21 of each period as the difference between phosphorus consumed from the diet and phosphorus excreted or secreted in feces, urine, and milk. A spot sample of urine (approximately $50 \mathrm{~mL}$ ) was collected between 4 and $5 \mathrm{~h}$ postfeeding (1300 to $1400 \mathrm{~h}$ ) on d 19 and 20 of each period. Estimated urine volume was calculated according to Valadares et al. (1999) as BW $(\mathrm{kg}) \times 29 \div$ creatinine (mg/L; kit DZ072B, Diazyme Laboratories, San Diego, CA). Diets, orts, feces, and milk were collected as previously described. Estimated fecal DM output was calculated as the amount of indigestible NDF consumed ( $\mathrm{g} / \mathrm{d}$ ) divided by the concentration of indigestible NDF in the feces (g/g of DM). Samples of feces, milk, and urine were analyzed for phosphorus by the same method used for the diets and orts (Dairy One). Phosphorus in urine was not detectable, so a value of $0 \mathrm{~g} / \mathrm{d}$ was used in the phosphorus balance calculation.

\section{Statistical Analyses}

Data for DMI, milk yield and composition, nutrient digestibility, phosphorus balance, BW, and BCS were 
Table 4. Particle size distribution of diets containing brown midrib sorghum-sudangrass silage (bmrSS) or corn silage (CS) at 35 or $45 \%$ of dietary DM

\begin{tabular}{|c|c|c|c|c|c|c|c|c|}
\hline \multirow[b]{3}{*}{ Item } & \multicolumn{8}{|c|}{ Diet } \\
\hline & \multicolumn{2}{|c|}{$35 \% \mathrm{bmrSS}$} & \multicolumn{2}{|c|}{$45 \%$ bmrSS } & \multicolumn{2}{|c|}{$35 \% \mathrm{CS}$} & \multicolumn{2}{|c|}{$45 \% \mathrm{CS}$} \\
\hline & Mean $^{1}$ & SD & Mean & $\mathrm{SD}$ & Mean & SD & Mean & $\mathrm{SD}$ \\
\hline Particle size fraction $^{2}$ & \multicolumn{8}{|c|}{ — retained (as-fed basis) } \\
\hline$>19.0 \mathrm{~mm}$ & 14.4 & 1.4 & 18.0 & 4.8 & 4.3 & 1.4 & 4.6 & 1.3 \\
\hline$>8.0$ to $19.0 \mathrm{~mm}$ & 30.1 & 1.7 & 35.0 & 1.6 & 24.2 & 1.8 & 28.2 & 2.9 \\
\hline 1.18 to $8.0 \mathrm{~mm}$ & 33.1 & 2.2 & 31.0 & 0.6 & 43.7 & 4.0 & 43.9 & 2.1 \\
\hline$<1.18 \mathrm{~mm}$ & 22.3 & 3.9 & 15.9 & 3.9 & 27.8 & 5.1 & 23.4 & 5.3 \\
\hline Particle size fraction ${ }^{3}$ & \multicolumn{8}{|c|}{$\%$ retained (DM basis) } \\
\hline$>19.0 \mathrm{~mm}$ & 1.8 & 0.3 & 2.9 & 1.8 & 0.4 & 0.2 & 0.3 & 0.2 \\
\hline$>13.2$ to $19.0 \mathrm{~mm}$ & 0.8 & 0.8 & 1.5 & 0.6 & 0.2 & 0.1 & 0.4 & 0.1 \\
\hline$>9.5$ to $13.2 \mathrm{~mm}$ & 1.7 & 0.8 & 2.2 & 0.6 & 1.4 & 0.4 & 1.8 & 0.3 \\
\hline$>6.7$ to $9.5 \mathrm{~mm}$ & 3.8 & 0.8 & 4.4 & 0.5 & 4.5 & 0.5 & 5.5 & 0.8 \\
\hline$>4.75$ to $6.7 \mathrm{~mm}$ & 5.1 & 0.7 & 6.9 & 0.7 & 6.2 & 0.6 & 7.0 & 0.8 \\
\hline$>3.35$ to $4.75 \mathrm{~mm}$ & 9.2 & 0.9 & 11.5 & 0.3 & 8.6 & 1.0 & 11.1 & 3.2 \\
\hline$>2.36$ to $3.35 \mathrm{~mm}$ & 9.7 & 1.7 & 11.0 & 0.7 & 9.2 & 1.6 & 10.8 & 1.5 \\
\hline$>1.18$ to $2.36 \mathrm{~mm}$ & 20.8 & 2.2 & 22.5 & 2.0 & 20.4 & 3.1 & 21.6 & 3.1 \\
\hline$>0.60$ to $1.18 \mathrm{~mm}$ & 25.0 & 3.0 & 22.1 & 0.7 & 23.8 & 1.6 & 21.9 & 1.6 \\
\hline$>0.30$ to $0.60 \mathrm{~mm}$ & 15.4 & 2.6 & 11.0 & 0.4 & 16.9 & 2.7 & 14.0 & 2.7 \\
\hline$<0.30 \mathrm{~mm}$ & 6.7 & 1.1 & 3.9 & 0.8 & 8.3 & 1.2 & 5.7 & 1.1 \\
\hline
\end{tabular}

${ }^{1}$ Mean of 4 composite samples (one per period).

${ }^{2}$ Determined with the Penn State Particle Separator (Lammers et al., 1996).

${ }^{3}$ Determined with the Ro-Tap sieve shaker (W. S. Tyler Combustion Engineering Inc., Mentor, OH).

analyzed as a replicated Latin square design (Latin rectangle) with model effects for period, diet, replicate, and cow within replicate using the MIXED procedure of SAS (version 8.02; SAS Institute, 2006). Cow was a random effect. Repeated measurements for performance data (i.e., DMI, milk yield, etc.) were reduced to period means for each cow before statistical analysis. Data for ruminal variables were analyzed as a single Latin square design with repeated measures by using the MIXED procedure of SAS. The model included the effects of period, diet, time, and the interaction of diet and time. Cow was a random effect. The PDIFF procedure of SAS was used to separate means for significant dietary effects. Unless otherwise stated, significance was declared at $P<0.05$. Data are reported as least squares means.

\section{RESULTS AND DISCUSSION}

\section{Silage and Dietary Chemical Composition}

Table 1 contains a detailed summary of the chemical composition of the silages and concentrates used in this study. The bmrSS silage was wetter than the CS (28.2 vs. $37.7 \%)$ and contained greater $\mathrm{CP}$ (10.8 vs. 7.2$)$. Originally, it was hoped that the CP content of the bmrSS silage would be closer to $15 \%$, but poor harvesting conditions delayed cutting and ensiling of the crop by several weeks. Because the difference in CP content between the bmrSS and the CS was less than expected, the difference in the amount of soybean meal (or CP supplement) between the bmrSS and CS diets also was less. Soy products contain substantial amounts of phosphorus, and feeding a higher CP forage would result in less use of purchased CP supplements, which only serve to bring phosphorus into the farm system. Although we could not capture that advantage in this study, presumably bmrSS harvested at a more immature stage would offer this advantage over corn hybrids because of their greater CP content.

The ADF, NDF, and lignin contents were greater for the bmrSS than for the CS. The 30- and 48-h in vitro NDF digestibility for the bmrSS was approximately 10 percentage units greater than for the CS hybrid. Previous research has also found high NDF digestion with bmr sorghum-sudangrass hybrids (Beck et al., 2004). Oliver et al. (2004) observed that the 48-h NDF digestibility was $6 \%$ greater for bmr- 6 forage sorghum than for a dual-purpose CS hybrid. The NFC content of the bmrSS was much less than for the CS, reflecting the substantial difference between the 2 crops in starch content (1.1 vs. $42.7 \%$ for bmrSS and CS, respectively). The fermentation profile of the 2 silages indicated that both were of good quality.

In addition to either 35 or $45 \%$ treatment silages, the diets contained alfalfa-grass silage (Table 1) and varying amounts of concentrates (Tables 2 and 3 ) to balance the diets for CP, MP production, and energyallowable milk using CPM-Dairy, version 3.0. The TMR 
Table 5. Performance data of cows fed diets containing brown midrib sorghum-sudangrass silage (bmrSS) or corn silage (CS) at 35 or $45 \%$ of dietary DM

\begin{tabular}{lcccccc}
\hline & \multicolumn{7}{c}{ Diet } & & \\
\cline { 2 - 5 } Item & $35 \%$ bmrSS & $45 \%$ bmrSS & $35 \%$ CS & $45 \%$ CS & SEM & $P$-value \\
\cline { 2 - 5 } DMI, kg/d & $20.1^{\mathrm{b}}$ & $17.6^{\mathrm{c}}$ & $23.4^{\mathrm{a}}$ & $23.2^{\mathrm{a}}$ & 0.6 & $<0.001$ \\
DMI, \% of BW/d & $3.06^{\mathrm{b}}$ & $2.71^{\mathrm{c}}$ & $3.62^{\mathrm{a}}$ & $3.58^{\mathrm{a}}$ & 0.09 & $<0.001$ \\
BW, kg & $663^{\mathrm{a}}$ & $655^{\mathrm{b}}$ & $649^{\mathrm{b}}$ & $656^{\mathrm{b}}$ & 3 & 0.003 \\
BW change, kg/21 d & $17.8^{\mathrm{a}}$ & $11.9^{\mathrm{a}}$ & $1.3^{\mathrm{b}}$ & $8.3^{\mathrm{ab}}$ & 3.7 & 0.02 \\
BCS & 3.23 & 3.22 & 3.29 & 3.25 & 0.04 & 0.63 \\
BCS change, unit/21 d & 0.04 & 0.02 & 0.13 & 0.10 & 0.06 & 0.56 \\
Milk yield & & & & & & \\
Milk, kg/d & $31.3^{\mathrm{ab}}$ & $28.9^{\mathrm{b}}$ & $32.7^{\mathrm{a}}$ & $30.9^{\mathrm{ab}}$ & 0.89 & 0.04 \\
3.5\% FCM, kg/d & 30.4 & 28.4 & 30.4 & 29.1 & 1.1 & 0.46 \\
SCM, kg/d & 27.4 & 25.4 & 28.0 & 26.4 & 1.0 & 0.22 \\
Milk composition & & & & & & \\
Fat, \% & 3.43 & 3.43 & 3.15 & 3.15 & 0.11 & 0.11 \\
Fat, kg/d & 1.04 & 0.98 & 1.00 & 0.97 & 0.05 & 0.69 \\
True protein, \% & $2.95^{\mathrm{a}}$ & $2.81^{\mathrm{b}}$ & $3.00^{\mathrm{a}}$ & $3.00^{\mathrm{a}}$ & 0.03 & $<0.001$ \\
True protein, kg/d & $0.88^{\mathrm{b}}$ & $0.79^{\mathrm{c}}$ & $0.97^{\mathrm{a}}$ & $0.90^{\mathrm{ab}}$ & 0.02 & $<0.001$ \\
Latose, \% & 4.66 & 4.57 & 4.72 & 4.56 & 0.06 & 0.15 \\
Lactose, kg/d & $1.47^{\mathrm{ab}}$ & $1.35^{\mathrm{b}}$ & $1.55^{\mathrm{a}}$ & $1.44^{\mathrm{ab}}$ & 0.04 & 0.02 \\
Urea nitrogen, mg/dL & $11.96^{\mathrm{a}}$ & $12.81^{\mathrm{a}}$ & $10.59^{\mathrm{b}}$ & $9.53^{\mathrm{b}}$ & 0.50 & $<0.001$ \\
SCS & 2.33 & 1.80 & 2.07 & 2.65 & 0.32 & 0.28 \\
Efficiency, kg/kg & & & & & \\
3.5\% FCM:DMI & $1.52^{\mathrm{a}}$ & $1.62^{\mathrm{a}}$ & $1.32^{\mathrm{b}}$ & $1.26^{\mathrm{b}}$ & 0.06 & $<0.001$ \\
SCM:DMI & $1.41^{\mathrm{a}}$ & $1.49^{\mathrm{a}}$ & $1.25^{\mathrm{b}}$ & $1.17^{\mathrm{b}}$ & 0.05 & $<0.001$ \\
\hline
\end{tabular}

${ }^{\mathrm{a}-\mathrm{c}}$ Least squares means within a row without a common superscript $\operatorname{differ}(P<0.05)$.

contained similar contents of CP, but the NDF content was 9 to 14 percentage units greater for the bmrSS diets (Table 3). In contrast, the starch content was 13.5 to 18.3 percentage units greater for the CS diets. The CS diets contained approximately $7.7 \%$ soybean hulls and between 8 and 17\% corn grain compared with the bmrSS diets, which contained no soybean hulls and only 19 to $28 \%$ corn grain. The particle size of the 2 silages differed (Table 4) despite the similar length of cut and roller settings on the field chopper. The bmrSS diet contained greater fractions of longer particles compared with the CS diets. Because of the subsequent potential for sorting, all calculations of nutrient digestibility were corrected for sorting (i.e., using the composition of orts).
In summary, the primary difference between the 2 silages was the composition of fibrous carbohydrates and NFC. Cows fed the bmrSS derived more energy from NDF fermentation, whereas cows fed the CS diets derived more energy from starch fermentation. This difference between the 2 silages and their respective diets corresponds well with the responses we observed in milk fat percentage, ruminal $\mathrm{pH}$, and ruminal acetate to propionate ratio.

\section{Lactational Performance}

Dry matter intake was greatest when cows were fed the 35 and $45 \%$ CS diets, least when they were fed the $45 \%$ bmrSS diet, and intermediate when they were fed

Table 6. Total tract nutrient digestibility (\% of DM) for cows fed diets containing brown midrib sorghumsudangrass silage (bmrSS) or corn silage (CS) at 35 or $45 \%$ of dietary DM

\begin{tabular}{lcccccc}
\hline & \multicolumn{7}{c}{ Diet } & & \\
\cline { 2 - 5 } Item & $35 \%$ bmrSS & $45 \%$ bmrSS & $35 \% \mathrm{CS}$ & $45 \% \mathrm{CS}$ & SEM & $P$-value \\
\hline $\mathrm{DM}, \%$ & $71.4^{\mathrm{b}}$ & $70.4^{\mathrm{b}}$ & $76.5^{\mathrm{a}}$ & $75.4^{\mathrm{a}}$ & 0.6 & $<0.001$ \\
OM & $73.2^{\mathrm{b}}$ & $72.3^{\mathrm{b}}$ & $77.7^{\mathrm{a}}$ & $76.7^{\mathrm{a}}$ & 0.6 & $<0.001$ \\
CP & $69.6^{\mathrm{b}}$ & $68.8^{\mathrm{b}}$ & $74.0^{\mathrm{a}}$ & $74.5^{\mathrm{a}}$ & 0.8 & $<0.001$ \\
$\mathrm{ADF}$ & $55.6^{\mathrm{n}}$ & 59.3 & 56.8 & 56.5 & 2.4 & 0.72 \\
NDF & 58.1 & 60.9 & 58.5 & 59.6 & 1.5 & 0.54 \\
Starch & 96.8 & 96.3 & 97.0 & 96.6 & 0.5 & 0.74 \\
NFC & 93.1 & 92.0 & 92.6 & 91.9 & 0.4 & 0.17 \\
Phosphorus & $41.5^{\mathrm{c}}$ & $37.2^{\mathrm{c}}$ & $56.3^{\mathrm{a}}$ & $49.1^{\mathrm{b}}$ & 2.4 & $<0.001$ \\
\hline
\end{tabular}

${ }^{\mathrm{a}-\mathrm{c}}$ Least squares means within a row without a common superscript $\operatorname{differ}(P<0.05)$. 
Table 7. Ruminal fermentation data of cows fed diets containing brown midrib sorghum-sudangrass silage (bmrSS) or corn silage (CS) at 35 or $45 \%$ of dietary DM

\begin{tabular}{|c|c|c|c|c|c|c|c|c|c|}
\hline \multirow[b]{2}{*}{ Item } & \multicolumn{4}{|c|}{ Diet } & \multirow[b]{2}{*}{ SEM } & \multicolumn{4}{|c|}{$P$-value } \\
\hline & $35 \%$ bmrSS & $45 \%$ bmrSS & $35 \% \mathrm{CS}$ & $45 \% \mathrm{CS}$ & & Diet & Period & Time & Diet $\times$ time \\
\hline Ruminal pH & $6.42^{\mathrm{b}}$ & $6.58^{\mathrm{a}}$ & $6.10^{\mathrm{c}}$ & $6.13^{\mathrm{c}}$ & 0.07 & $<0.001$ & 0.008 & $<0.001$ & 0.19 \\
\hline Total VFA, mM & 115.6 & 114.2 & 131.2 & 126.5 & 7.9 & 0.29 & 0.07 & 0.002 & 0.23 \\
\hline VFA, $\mathrm{m} M$ & & & & & & & & & \\
\hline Acetate (A) & 70.4 & 70.3 & 75.7 & 73.0 & 3.8 & 0.71 & 0.24 & 0.005 & 0.37 \\
\hline Propionate (P) & $26.7^{\mathrm{b}}$ & $25.9^{\mathrm{b}}$ & $34.1^{\mathrm{a}}$ & $32.0^{\mathrm{ab}}$ & 3.3 & 0.05 & 0.01 & $<0.001$ & 0.07 \\
\hline Butyrate (B) & 14.7 & 14.0 & 16.2 & 16.9 & 1.1 & 0.11 & 0.12 & 0.008 & 0.43 \\
\hline Isobutyrate & $1.1^{\mathrm{bc}}$ & $1.0^{\mathrm{c}}$ & $1.2^{\mathrm{ab}}$ & $1.3^{\mathrm{a}}$ & 0.1 & 0.002 & 0.10 & 0.04 & 0.57 \\
\hline Valerate & 2.4 & 2.4 & 3.1 & 2.9 & 0.4 & 0.43 & $<0.001$ & 0.11 & 0.79 \\
\hline Isovalerate & 0.4 & 0.5 & 0.8 & 0.4 & 0.2 & 0.37 & $<0.001$ & 0.24 & .83 \\
\hline$A: P$ & $2.69^{\mathrm{a}}$ & $2.84^{\mathrm{a}}$ & $2.40^{\mathrm{b}}$ & $2.42^{\mathrm{b}}$ & 0.19 & $<0.001$ & $<0.001$ & $<0.001$ & 0.32 \\
\hline$(A+B): P$ & $3.24^{\mathrm{ab}}$ & $3.39^{\mathrm{a}}$ & $2.92^{\mathrm{c}}$ & $2.98^{\mathrm{bc}}$ & 0.23 & 0.003 & $<0.001$ & $<0.001$ & 0.53 \\
\hline
\end{tabular}

${ }^{\mathrm{a}-\mathrm{c}}$ Least squares means within a row without a common superscript differ $(P<0.05)$.

the $35 \%$ bmrSS diet (Table 5). There was little difference in average BW or BCS among cows on the different dietary treatments (Table 5). Body weight gain was greater when cows were fed the bmrSS diets than when they were fed the $35 \%$ CS diet (Table 5), although the change in BCS was unaffected by diet. The treatment periods in this study were only $21 \mathrm{~d}$ in length, and these positive $\mathrm{BW}$ and body condition results need to be verified with a longer term lactation study.

The 3.5\% FCM and SCM yields were similar among dietary treatments (Table 5). The content and yield of milk fat were not different among dietary treatments, although the milk fat percentage tended to be reduced for cows fed the CS diets $(P<0.11)$. In contrast, the content and yield of milk protein were lowest when cows consumed the $45 \%$ bmrSS diet. Importantly, gross efficiency of milk production, expressed as kilograms of $3.5 \%$ FCM or SCM per kilogram of DMI, was approximately $28 \%$ greater when cows were fed the bmrSS diets than when they were fed the CS diets (Table 5). Previous research with bmr forage sorghum (Oliver et al., 2004) found increased efficiency of FCM production compared with a non-bmr control, although efficiency was similar to the CS hybrid evaluated in that study. Lusk et al. (1984) also observed similar milk production when cows were fed either a bmr forage sorghum or a dual-purpose corn hybrid. The efficiency of milk production for cows fed the bmrSS (1.52 and 1.62) was within the recommended range for healthy, productive cows, whereas the efficiency for cows fed the CS diets (1.26 and 1.32) was lower than recommended and was within a range often associated with subacute ruminal acidosis and lower fiber digestion (Britt et al., 2003). As with the BW and body condition data, a longer term lactation study would be required to fully assess the effect of forage source on feed efficiency.

\section{Nutrient Digestibility and Ruminal Fermentation}

In vivo total tract apparent digestibilities of $\mathrm{DM}, \mathrm{OM}$, and $\mathrm{CP}$ were greater for the CS diets than for the bmrSS diets (Table 6). It is not surprising that DM digestibility was greater for the CS diets because CS DM digestibility at 30 and $48 \mathrm{~h}$ was greater than bmrSS silage digestibility at 30 and $48 \mathrm{~h}$ (Table 1 ). This high DM digestibility reflects the greater content of starch in the CS compared with the bmrSS. Despite the greater total tract DM digestibility, the greater efficiency of milk production likely reflects improved ruminal conditions for cows fed the bmrSS diet compared with the CS diet (discussed in the next section).

Table 8. Intake, excretion, and secretion of phosphorus for cows fed diets containing brown midrib sorghumsudangrass silage (bmrSS) or corn silage (CS) at 35 or $45 \%$ of dietary DM

\begin{tabular}{lcccccc}
\hline & \multicolumn{9}{c}{ Diet } & & \\
\cline { 2 - 5 } Item & $35 \%$ bmrSS & $45 \%$ bmrSS & $35 \% \mathrm{CS}$ & $45 \% \mathrm{CS}$ & SEM & $P$-value \\
\hline Dietary phosphorus intake, g/d & $71.3^{\mathrm{b}}$ & $55.7^{\mathrm{c}}$ & $83.7^{\mathrm{a}}$ & $82.0^{\mathrm{a}}$ & 2.4 & $<0.001$ \\
Fecal phosphorus excretion, g/d & 41.8 & 36.2 & 36.7 & 41.9 & 2.0 & 0.08 \\
Milk phosphorus secretion, g/d & $29.5^{\mathrm{b}}$ & $26.5^{\mathrm{c}}$ & $32.3^{\mathrm{a}}$ & $30.1^{\mathrm{ab}}$ & 1.0 & 0.002 \\
Phosphorus balance, g/d & $-0.1^{\mathrm{b}}$ & $-7.0^{\mathrm{c}}$ & $14.6^{\mathrm{a}}$ & $10.1^{\mathrm{a}}$ & 2.3 & $<0.001$ \\
\hline
\end{tabular}

${ }^{a-c}$ Least squares means within a row without a common superscript differ $(P<0.05)$. 
The greater phosphorus digestibility with the CS diets was not expected. In contrast, Oliver et al. (2004) found that total tract apparent phosphorus digestibility was improved significantly for bmr-6 forage sorghum compared with the CS hybrid evaluated. Digestibilities of ADF, NDF, starch, and NFC were similar among dietary treatments (Table 6). Similarly, Aydin et al. (1999) observed no significant difference in total tract NDF digestibility between bmr forage sorghum and CS.

Mean ruminal $\mathrm{pH}$ was highest when cows were fed the $45 \%$ bmrSS diet, lowest when they were fed the 35 and $45 \%$ CS diets, and intermediate when they were fed the $35 \%$ bmrSS diet (Table 7). There was no interaction of dietary treatment and time, indicating that $\mathrm{pH}$ changed similarly among dietary treatments relative to feeding time. The nadir was greater than 5.2 for all observations. Total VFA concentrations were similar among diets, but the acetate to propionate ratio was greater for the bmrSS diets than for the CS diets (Table 7). Oliver et al. (2004) also observed a higher acetate to propionate ratio when cows consumed bmr forage sorghum compared with $\mathrm{CS}$. The higher ruminal $\mathrm{pH}$ and acetate to propionate ratio for cows fed the bmrSS vs. the CS corresponds well with the other responses of increased milk production efficiency and greater milk fat percentage. Clearly, the strategy of obtaining energy from digestible NDF rather than excessive amounts of starch was associated with more optimal ruminal conditions and greater productive efficiency in this short-term study.

Dietary intake of phosphorus was greater for the CS diets than for the bmrSS diets (Table 8) because DMI was greater for the CS diets than for the bmrSS diets (Table 5). At the $45 \%$ forage level, bmrSS resulted in a trend for less fecal phosphorus excretion than did the CS diet $(P<0.08$; Table 8). Milk phosphorus secretion was greatest for the $35 \%$ CS diet. Excretion of phosphorus was driven by milk yield. Differences in DMI, milk secretion, and digestibility of phosphorus resulted in a higher phosphorus balance for the CS diets than for the bmrSS diets (Table 8). The CS diets had a positive balance and the bmrSS diets had a slightly negative balance across forage levels in the diet. To put these phosphorus retention and excretion values into perspective, consider the following comparison. At the $45 \%$ forage level, bmrSS resulted in approximately $6 \mathrm{~g} / \mathrm{d}$ less fecal phosphorus excretion than the CS diet. A reduction in total ration phosphorus content from 0.43 to $0.39 \%$ would result in approximately the same reduction in fecal phosphorus excretion $(\sim 6.5 \mathrm{~g} / \mathrm{d})$. Both strategies would theoretically result in approximately 1.8 $\mathrm{kg}$ less phosphorus excretion per cow per 305-d lactation. This amount of reduction in phosphorus excretion is potentially important. We need to have a surer under- standing of the net impact of bmrSS or forage sorghum hybrids on phosphorus retention and excretion, at various levels of dietary inclusion, to make specific recommendations.

\section{CONCLUSIONS}

Feeding bmrSS in place of a common CS hybrid at either 35 or $45 \%$ of dietary DM resulted in greater efficiency of milk production, a higher milk fat percentage, an equivalent SCM yield, higher ruminal $\mathrm{pH}$, and higher acetate to propionate ratio, with similar total tract OM digestion. The bmrSS had greater in vitro NDF digestibility, whereas the CS had greater DM digestibility; cows fed the bmrSS derived more energy from digestion of NDF compared with cows fed the CS, which relied more on starch digestion. This short-term study indicates potential for this bmrSS hybrid to compete nutritionally with CS in diets for lactating dairy cows. However, a longer term lactation study would be needed to draw unequivocal conclusions regarding changes in BW, BCS, or efficiency of lactation.

\section{ACKNOWLEDGMENTS}

The authors thank the staff at the Miner Institute dairy research barn for their assistance in conducting this experiment.

\section{REFERENCES}

AOAC. 2000. Official Methods of Analysis. 17th ed. AOAC Int., Arlington, VA.

Aydin, G., R. J. Grant, and J. O’Rear. 1999. Brown midrib sorghum in diets for lactating dairy cows. J. Dairy Sci. 82:2127-2135.

Beck, P. A., J. M. Phillips, S. Hutchison, T. Losi, C. B. Stewart, P. K. Capps, and S. A. Gunter. 2004. Effect of harvest date and brown midrib gene on in situ disappearance of sorghum $\times$ sudangrasss hybrids. J. Anim. Sci. 82(Suppl. 1):249. (Abstr.)

Britt, J. S., R. C. Thomas, N. C. Speer, and M. B. Hall. 2003. Efficiency of converting nutrient dry matter to milk in Holstein herds. J. Dairy Sci. 86:3796-3801.

Fritz, J. O., K. J. Moore, and E. H. Jaster. 1990. Digestion kinetics and cell wall composition of brown midrib sorghum $\times$ sudangrass morphological components. Crop Sci. 30:213-219.

Goering, H. K., and P. J. Van Soest. 1970. Forage Fiber Analysis (Apparatus, Reagents, Procedures, and Some Applications). Agric. Handb. No. 379. ARS-USDA, Washington, DC.

Grant, R. J., S. G. Haddad, K. J. Moore, and J. F. Pedersen. 1995. Brown midrib sorghum silage for midlactation dairy cows. J. Dairy Sci. 78:1970-1980.

Hall, M. B., W. M. Hoover, J. P. Jennings, and T. K. Miller Webster. 1999. A method for partitioning neutral detergent soluble carbohydrates. J. Sci. Food Agric. 79:2079-2086.

Kilcer, T., Q. Ketterings, P. Cerosaletti, J. Cherney, P. Barney, M. Hunter, G. Godwin, and G. Albrecht. 2001. Successfully growing brown midrib sorghum-sudan for dairy cows in the northeast. http://www.cce.cornell.edu/rensselaer/agriculture Accessed May $22,2007$.

Kononoff, P. J., A. J. Heinrichs, and D. R. Buckmaster. 2003. Modification of the Penn State Forage and Total Mixed Ration Particle Separator and the effects of moisture content on its measurements. J. Dairy Sci. 86:1858-1863. 
Lammers, B. P., D. R. Buckmaster, and A. J. Heinrichs. 1996. A simplified method for the analysis of particle sizes of forage and total mixed rations. J. Dairy Sci. 79:922-928.

Licitra, G., T. M. Hernandez, and P. J. Van Soest. 1996. Standardization of procedures for nitrogen fractionation of ruminant feeds. Anim. Feed Sci. Technol. 57:347-358.

Lusk, S. W., P. K. Karau, D. O. Balogu, and L. M. Gourley. 1984. Brown midrib sorghum or corn silage for milk production. J. Dairy Sci. 67:1739-1744.

Maynard, L. A., J. K. Loosli, H. F. Hintz, and R. G. Warner. 1979. Digestive processes in different species. Pages 21-46 in Animal Nutrition. McGraw-Hill Inc., New York, NY.

Oliver, A. L., R. J. Grant, J. F. Pedersen, and J. O’Rear. 2004. Comparison of brown midrib- 6 and -18 forage sorghum with conventional sorghum and corn silage in diets of lactating dairy cows. J. Dairy Sci. 87:637-644.

Porter, K. S., J. D. Axtell, V. L. Lechtenberg, and V. F. Colenbrander. 1978. Phenotype, fiber composition, and in vitro dry matter disappearance of chemically induced brown midrib (bmr) mutants of sorghum. Crop Sci. 18:205-208.

Roe, M. B., and C. J. Sniffen. 1990. Techniques for measuring protein fractions in feedstuffs. Pages 81-88 in Proc. Cornell Nutr. Conf., Rochester, NY. Cornell University, Ithaca, NY.

Sanderson, M. A., R. M. Jones, J. Ward, and R. Wolfe. 1992. Silage sorghum performance trial at Stephensville: Forage research in Texas. Rep. PR-5018. Texas Agric. Exp. Stn., Stephensville.
SAS Institute. 2000. SAS/STAT User's Guide. Release 8.02. SAS Inst. Inc., Cary, NC.

Sirois, P. K., M. J. Reuter, C. M. Laughlin, and P. J. Lockwood. 1994. A method for determining macro and micro elements in forages and feeds by inductively coupled plasma atomic emission spectrometry. Spectroscopist 3:6-9.

Smith, D. 1969. Removing and analyzing total nonstructural carbohydrates from plant tissue. Res. Rep. 41. Wisconsin Agric. Exp. Stn., Madison.

Tyrrell, H. F., and J. T. Reid. 1965. Prediction of the energy value of cow's milk. J. Dairy Sci. 48:1215-1223.

Valadares, R. F. D., G. A. Broderick, S. C. Valadares Filho, and M. K. Clayton. 1999. Effect of replacing synthesis estimated from excretion of total purine derivatives. J. Dairy Sci. 82:2686-2696.

Van Soest, P. J., J. B. Robertson, B. A. Lewis, and D. E. Akin. 1991. Methods for dietary fiber, neutral detergent fiber, and nonstarch polysaccharides in relation to animal nutrition. J. Dairy Sci. 70:3583-3597.

Vogel, K. P., and H. G. Jung. 2001. Genetic modification of herbaceous plants for feed and fuel. Crit. Rev. Plant Sci. 20:15-49.

Wildman, E. E., G. M. Jones, P. E. Wagner, R. L. Boman, H. F. Troutt, and T. N. Lesch. 1982. A dairy cow body condition scoring system and its relationship to selected production characteristics. J. Dairy Sci. 65:495-501. 